\title{
Quantification of cortical neurons: a neuroanatomical myth in neuroscience
}

\author{
PARRA, J. E. D. ${ }^{1,2 *}$, AGUIRRE, J. F. G. ${ }^{1,2}$ and MEJÍA, F. R. ${ }^{1}$ \\ ${ }^{1}$ Laboratory of Neurophysiology, Departamento de Ciencias Básicas Biológicas, Facultad de Salud, \\ Universidad Autónoma de Manizales, Antigua Estación del Ferrocarril, 170017, Manizales, Caldas, Colombia \\ ${ }^{2}$ Programa de Medicina, Departamento de Ciencias Básicas, Facultad de Ciencias para la Salud, \\ Universidad de Caldas, Street 65 26-10, 170017, Manizales, Caldas, Colombia \\ *E-mail: jorge.duque_p@ucaldas.edu.co
}

\begin{abstract}
The objective was to analyze whether there was a definite number of cerebral cortical neurons for humans. Methodology: data was examined for the total number of brain neurons in the literature related to the field of neuroscience. This suggested that the human cerebral cortex has a large number of neurons whose value changes with the life cycle due to several factors that lead to have an indefinite number. Discussion: an analysis based on the literature showed the main factors influencing the total number of cortical neurons such as neurogenesis, apoptosis during life cycle, gender and pathological conditions. The inconsistent assessment of the number of neurons in the human cortex has been discussed by several authors, emphasizing that the values that have been displayed in the literature are presumably uncertain and are based on the views of some authors or the conceptions of others without carrying out replicable scientific studies. The above described has exhibited variable and inconsistent values in different texts about this issue. It has been concluded that the total number of cortical neurons varies due to diverse factors that play a role in determining the number of neurons in the human cerebral cortex.
\end{abstract}

Keywords: cortex brain, neuron, quantification of neurons, neuroanatomy, neuroscience.

\section{Introduction}

Human brain analyzed from its evolutionary development seems to change more from a quantitatively than from a qualitatively perspective. This leads to consider that human capabilities are a specific product of quantitative changes in specialized areas instead of neuroanatomical changes (CARROLL, 2003). This may be true even for other mammals, a fact that has been demonstrated in rodents, since most encephalized species exhibit an apparent excess in the number of expected neurons in proportion to their body size. This could be due to a cognitive advantage in such species (HERCULANOHOUZEL, 2007).

\section{Materials and Methods}

Different literature sources, some of them key sources on Neuroanatomy and Neuroscience, and some journals on the number of neurons of the cerebral cortex were analyzed. The values were matched with those relating to variations regarding the number of neurons throughout the life cycle and disorders of gender and health condition.

\section{Results}

In the cerebral cortex, the most complex structure of the central nervous system of mammals can be clearly observed that one of the changes occurring during evolution has been a quantitative one. The grey matter, an essential part of the nervous system, contains the somas of neurons in clusters located below the cortical surface; its development, structural and functional characteristics are initially regulated by different mechanisms. Studying the histological structure of the cerebral cortex from a comparative anatomy perspective indicates that it has remained essentially unchanged. This feature has been observed in research that shows a diagrammatic section of the dominant pyramidal cells in laminae II, III and IV basically the same for a cat, a monkey or a human (ECCLES, 2005). In other animals such as cetaceans some layers show an evident variation, i.e, layer IV is absent or poorly developed (ERIKSEN and PAKKENBERG, 2007). Regarding the quantitative analysis, the most important development has been to the neocortex, especially for Homo sapiens sapiens, because if you compare them with other species like Pongidae (gibbons, chimpanzees and gorillas), you can observe that the human neocortex is three times greater than that of such species, considering that in total, nine-tenths of the human cerebral cortex correspond to the neocortex (KIERNAN, 2000).

\subsection{Quantification of neurons}

Historically, different methods have been used for general quantification of the number of neurons in the cerebral cortex (KONIGSMARK, 1970) and various techniques have been developed to estimate the number of cells in the nervous system (ERIKSEN and PAKKENBERG, 2007) (BRODY and VIJAYASHANKAR, 1977). Among these techniques, there are the photographic, the projection, the microphotometric, the 
homogenate, direct microscopic count methods and automated processes. It has been highlighted the fact that even by using the same procedure in different brains of individuals of the same species, it has been found a variability ranging between 19 and 33\% (SKOGLUND, PASCHER and BERTHOLD, 1996). Perhaps on that basis, several authors have established a definite number of neurons from the nineteenth century to the present day, exhibiting quite different values. Most of the authors who mention a value for neurons in the cerebral cortex, do not clarify the method used to do this consideration. All the following values are given in number of millions of neurons: some studies only make a theoretical approach, 1000 (LURIJA, 1977), 2500 (RUBIA, 1998), 11500 (DICKE and ROTH, 2009), 14000 (GUBERMAN, 1972), 10000 to 20000 (PAVON, VIDAL, BLANCO et al., 1998) (NOLTE, 1994) (NOWAKOWSKI, 1987), 30000 (DUQUE-PARRA and JAIRO, 1999), $10^{11}$ (KANDEL, BARRES and KUDSPETH, 2013), other authors have done microphotometric studies, 50000 to 100000 (ARANA INIGUEZ and REBOLLO, 1979), (ROSENZWEIG, LEIMAN, PAMIES et al., 1992) o direct microscopic studies: 50000 to 80000 (BLOOM, 1988; COWAN, 1979), 100000 (GUYTON and HALL, 2001; FUSTER, 2004; THAGARD, 2008; GAGE and MUOTRI, 2012), 100,000 to 150,000 (AYAN, 2011), 100,000 to 200,000 (BERK, 1999), $2.6 \times 10^{9}$ and $1.6 \times 10^{10}$ (KIERNAN, SIMÓN, PAZOS et al., 2009), and finally, other studies have used an optical dissector, referring numbers of $38.4 \times 10^{9}$ (ERIKSEN and PAKKENBERG, 2007). Other authors have displayed values only for the neocortex, that can contain up to $70 \%$ of all neurons of the central nervous system (TORRES, 1999).

\subsection{Neurogenesis and apoptosis during life cycle}

The human cerebral cortex in the fifth month of fetal life seems to take its total nerve cells estimated between 50 to 100 million (GUYTON and HALL, 2001). Similarly, it has been pointed out that the majority of neurons in the neocortex is generated in the ventricular and sub-ventricular areas and then is deposited in the cortex by a migration mechanism that follows a sequence from the inside to outside, which ends before birth in primates. It should be noted that in the cerebral cortex more than $50 \%$ of the neurons of layers II to IV die (ÁLVAREZ and LOIS, 1998). Likewise, during development of the vertebrate nervous system, $50 \%$ or more of neurons normally die during embryogenesis (PAVON, VIDAL, BLANCO et al., 1998). This apoptotic cell death as a suicide process occurring in the cerebral cortex (CHAN, LORKE, TIU et al., 2002) (DUQUE-PARRA, 2005), is a process that limits the number of neurons and allows the establishment of optimal interconnections among them. Neurons receive molecules that allow them to keep their trophism and survive. The neurotrophic mechanism involved turns out to be an advantage for the nervous system as it ensures that the neurons projecting to an improper area be automatically removed The biggest evidence supporting this finding comes from the sympathetic sensory neurons that depend on the nerve growth factor for their development (KORSCHING and THOENEN, 1998). In a healthy adult brain, there are areas of neurogenesis in the olfactory bulb (GÖKHAN and MEHLER, 2001) (RAO, 1999) and the dentate gyrus of the hippocampus (GÖKHAN and MEHLER, 2001; RAO, 1999; CAMERON and MCKAY, 1999), -evidence shown in postmortem brain tissue of patients treated with thymidine analogues such as de bromodeoxyuridine (BrdU) (ERIKSSON, PERFILIEVA, BJÖRK-ERIKSSON et al., 1998)-, where several thousand neurons are daily formed. Neurogenesis in these areas seems to have a peak of development in the first week of postnatal life (RAO, 1999).

\subsection{Gender}

Regarding the gender, a study of postmortem cerebral cortex, showed that the neocortex of the human brain had a total average of 19 billion neurons in women and 23 billion in men, attributing to gender $21 \%$ of the variance in the total number of neurons in the neocortex (PAKKENBERG and GUNDERSEN, 1997). This data shows how gender can also become a determining factor of the total number of neurons in the neocortex. However, there has been no consensus, due to divergent results shown in MRI studies with living individuals that have showed a significant increase in the thickness of the total cortex found in women compared to men (LUDERS, NARR, THOMPSON et al., 2006). The thickness of the cortex has been linked to cellular features such as cell size and number of cortical neurons, suggesting that the female brain can actually have a bigger number of neurons in contrast with the male brain. Also, the female brain, despite of being about 100-150 $\mathrm{cm}^{3}$ smaller than the male brain (PAKKENBERG and GUNDERSEN, 1997), is able to adapt a bigger cortex portion due to a fold greater complexity (LUDERS, NARR, THOMPSON et al., 2006).

\subsection{Brain aging}

Neurogenesis and neuronal death both continue throughout adulthood. A healthy person that reaches the age of 90 has lost up to $20 \%$ of all his/her neurons (TORRES, 1999). In aged humans, it has been observed a decrease in the density of pyramidal neurons and in the total volume of the hippocampal formation. It has also been stated that the great majority of asymptomatic individuals over 55 have at least a few neurons in transition to form neurofibrillary tangles in layer II of the entorhinal cortex (CAMERON and MCKAY, 1999). Aged brains have been studied reporting a decrease in the number of cells in several brain areas. This neuronal reduction occurs in all layers, being layer II and IV the ones with the highest reduction (BRODY and VIJAYASHANKAR, 1977). A neuronal reduction in the temporal lobe, particularly in the superior temporal gyrus at a frontal pole has also been reported. In the frontal lobe, this reduction was found in the ascending frontal gyrus and the superior frontal gyrus in the fifth and ninth decades of life (HANLEY, 1974). In the limbic system, the loss has been found in neurons of the cingulate gyrus in the ninth decade of life and it has been suggested that during each day of adulthood over 100,000 neurons die (BURNS, 1958).

\subsection{Pathological conditions}

The total number of cortical neurons has also been affected in the pathological conditions, because the microglial cells that act as macrophages residing in the CNS (KREUTZBERG, 1996) record all changes in the homeostasis and become very reactive for most neuropathological conditions (STREIT, 2000). It has been described neuronal dysfunction, the presence of abnormal protein aggregates (VILHARDT, 2005), interaction with cytokines or with bacterial products such as lipopolysaccharide, subsequent trauma disruption of tissue and 
Table 1. Number of cortical neurons.

\begin{tabular}{cl}
\hline Number of million cortical-cerebral neurons & \multicolumn{1}{c}{ Reference } \\
\hline $\mathbf{1 0 0 0}$ & Lurija (1977) \\
$\mathbf{1 1 5 0 0}$ & Rubia (1998) \\
$\mathbf{1 4 0 0 0}$ & Dicke and Roth (2009) \\
$\mathbf{1 0 0 0 0 - 2 0 0 0 0}$ & Guberman (1972) \\
$\mathbf{3 0 0 0 0}$ & Pavon, Vidal, Blanco et al. (1998) \\
$\mathbf{5 0 0 0 0 - 8 0 0 0 0}$ & Nolte (1994), Duque-Parra and Jairo (1999) \\
& Duque-Parra and Jairo (1999), Rosenzweig, Leiman, \\
$\mathbf{5 0 0 0 0 - 1 0 0 0 0 0}$ & Pamies et al. (1992), Bloom (1988) \\
$\mathbf{1 0 0 0 0 0}$ & Cowan (1979) \\
$\mathbf{1 0 0 0 0 0 - 2 0 0 0 0 0}$ & Arana-Iñiguez and Rebollo (1979), Guyton and Hall (2001), \\
$\mathbf{2 . 6} \mathbf{1 0}^{9}-\mathbf{1 . 6} \times \mathbf{1 0}^{\mathbf{1 0}} \mathbf{3 8 . 4} \mathbf{1 0}^{9-10^{11}}$ & Fuster (2004), Thagard (2008), Gage and Muotri (2012) \\
& Berk (1999) \\
& Kiernan (2009), Eriksen and Pakkenberg (2007), Kandel, Barres and \\
\hline
\end{tabular}

the release of intracellular contents after ischemic events, among others. Glial function consists of removing dead cells and other debris such as axon degeneration that also plays an important role in the recruitment of T cells (KALLA, LIU, XU et al., 2001), serving as a link between the neural parenchyma and immune system (HANLEY, 1974). As it produces many factors (IL-1, TNFa, NO, PGE2, superoxide ion) that are toxic to neurons. Microglia in an active state generates an extension of neuronal damage, as the inflammatory response causes a greater damage and neuronal death, resulting in a cycle that disseminates the destruction of neural tissue (BLOCK and HONG, 2005).

\section{Discussion}

The analysis of values reported in the literature regarding quantification of neurons (see Table 1) leads to have doubts about them. The extrapolation arising from multiplying the number of modules, cortical columns or cyto-architectural areas (that are composed by smaller units arranged in repeated neural circuits within each area (ECCLES, 2005; MOUNTCASTLE, 1997) and are about two million), per the number of neurons in each one: 10000 (POPPER and ECCLES, 1982; KOCH, 1997 ) provides a total number of 200 billion cortical neurons. If this number is compared to the newborn being referred between 50 and 100 million at birth (COWAN, 1979), and considering that in adult humans millions of cells die every minute, there is a loss of at least 199.9 billion neurons. This value may represent a high percentage of cells that may die by apoptosis between birth and adulthood. It is evident that this value would not be true, because it would lead to recognize that cerebral cortical apoptosis takes priority over neurogenesis with a value as high as $99.99999995 \%$ of cells that die and a living population of neurons that represent the remaining $0.00000005 \%$. Therefore, it is confirmed that the stated values of quantification of neurons are inconsistent and that the value of multiplying the number of modules by the number of neurons, although coincides with the above mentioned of 200 billion (ECCLES, 2005; TORRES, 1999), takes leave to doubt based on related values reported by other authors. This fact shows indefinite number of neurons in the human cerebral cortex.
Taking into account mainly the following: 1 . From the fifth week of intrauterine life in the sub-ventricular zone occurs cell proliferation and apoptotic nuclei are observed. 2 . The spatial distribution of apoptosis extends into late gestation (CHAN, LORKE, TIU et al., 2002). 3. The destruction of a significant part of a neuronal population triggers a focal reactive neurogenesis during different pathological conditions. 4. In adulthood, neurogenesis processes and neuronal death take place. 5 . The gender is a major factor of the number of neurons in the cortex, but still there is no consensus on its precise impact. Therefore, establishing a number of cortical neurons in humans is very risky since it can be argued that there is not a definite number and, data on quantification of cortical neurons should focus on a particular moment in the life cycle, taking into account the gender, health condition, neurogenesis and apoptosis, that is, knowing exactly how many neurons are generated and how many die every day at the same time.

\section{Conclusion}

The number of neurons in the cerebral cortex is variable and depends on gender, condition of life cycle, health condition or pathological disorders; therefore, literature data become inconsistent. Apparently the maximum number of neurons is reached at the end of prenatal life, as the conditions of neurogenesis are widely activated. However, over time, although neurogenesis continues, this occurs in a restricted way without being able to accurately estimate the number of neurons of the cerebral cortex. This fact makes the reported data on quantification of cortical neurons become a myth of the Neuroanatomy extrapolated to the Neuroscience.

\section{References}

ÁLVAREZ, A. and LOIS, C. Mecanismos de desarrollo y plasticidad del sistema nervioso central. DE LA FUENTE, R. and ALVAREZ FJ. Biología de la mente. México: Fondo de Cultura Económica, 1998. p. 105-146.

ARANA IÑIGUEZ, R. and REBOLLO, MA. Neuroanatomía. Buenos Aires: Inter-Médica, 1979. 
AYAN, S. Ejercicio corporal para la mente. Mente y cerebro, 2011, vol. 47 , p. 23-31.

BERK, L. Desarrollo del niño y del adolescente. Madrid: Prentice May Iberia, 1999.

BLOCK, ML. and HONG, J-S. Microglia and inflammation-mediated neurodegeneration: multiple triggers with a common mechanism. Progress in Neurobiology, 2005, vol. 76, n. 2, p. 77-98. PMid:16081203. http://dx.doi.org/10.1016/j.pneurobio.2005.06.004.

BLOOM, FE. Drogas que actúan sobre el sistema nervioso central. Transmisión neurohumoral y sistema nervioso central. In GOODMAN, G. Las bases farmacológicas de la terapéntica. Buenos Aires: Editorial Médica Panamericana, 1988. p. 239-260.

BRODY, H. and VIJAYASHANKAR, N. Anatomical changes in the nervous system. In FINCH, C. and HAYFLICK, L. (Eds.). Handbook of the biology of aging. New York: Van Nostrand Reinhold, 1977. vol. 1, p. 241-261

BURNS, BD. The mammalian cerebral cortex. London: Arnold, 1958.

CAMERON, HA. and MCKAY, RD. Restoring production of hippocampal neurons in old age. Nature Neuroscience, 1999, vol. 2 , n. 10, p. 894-897. PMid:10491610. http://dx.doi.org/10.1038/13197.

CARROLL, SB. Genetics and the making of Homo sapiens. Nature, 2003, vol. 422, n. 6934, p. 849-857. PMid:12712196. http://dx.doi. org/10.1038/nature01495.

CHAN, WY., LORKE, DE., TIU, SC. and YEW, DT. Proliferation and apoptosis in the developing human neocortex. The Anatomical Record, 2002, vol. 267, n. 4, p. 261-276. PMid:12124904. http:// dx.doi.org/10.1002/ar.10100.

COWAN, WM. The development of the brain. Scientific American, 1979, vol. 241, n. 3, p. 113-133. PMid:493917. http://dx.doi. org/10.1038/scientificamerican0979-112.

DICKE, U. and ROTH, G. Evolución de la inteligencia. Mente y Cerebro, 2009, vol. 35, p. 12-19.

DUQUE-PARRA, JE. and JAIRO, DJ. Una visión integrativa de la corteza cerebral. Selecta Médica, 1999, vol. 10, p. 46-48.

DUQUE-PARRA, JE. Note on the origin and history of the term “apoptosis". Anatomical Record. Part B, New Anatomist, 2005, vol. 283, n. 1, p. 2-4. PMid:15761829. http://dx.doi.org/10.1002/ ar.b.20047.

ECCLES, JC. Evolution of the brain: creation of the self. New York: Routledge, 2005.

ERIKSEN, N. and PAKKENBERG, B. Total neocortical cell number in the mysticete brain. The Anatomical Record, 2007, vol. 290, n. 1, p. 83-95. PMid:17441201. http://dx.doi.org/10.1002/ar.20404.

ERIKSSON, PS., PERFILIEVA, E., BJÖRK-ERIKSSON, T., ALBORN, A-M., NORDBORG, C., PETERSON, DA. and GAGE, FH. Neurogenesis in the adult human hippocampus. Nature Medicine, 1998, vol. 4, n. 11, p. 1313-1317. PMid:9809557. http://dx.doi. org/10.1038/3305.

FUSTER, J. La mamoria. In MORA, F. (Ed). Esplendores y miserias del cerebro. Madrid: Fundación Santander Hispano, 2004. p. 182-202.

GAGE, FH. and MUOTRI, AR. La singularidad de cada cerebro. Investigacion y Ciencia, 2012, vol. 14, p. 9.

GÖKHAN, Ş. and MEHLER, MF. Basic and clinical neuroscience applications of embryonic stem cells. The Anatomical Record, 2001, vol. 265, n. 3, p. 142-156. PMid:11458329. http://dx.doi. org/10.1002/ar.1136.

GUBERMAN, I. El cerebro (la caja negra) prodigios y tragedias. Buenos Aires: Cartago, 1972.
GUYTON, A. and HALL, J. Tratado de fisiología médica. Madrid: Mc Graw-Hill Interamericana, 2001.

HANLEY, T. 'Neuronal fall-out'in the ageing brain: a critical review of the quantitative data. Age and Ageing, 1974, vol. 3, n. 3, p. 133151. PMid:42 19098. http://dx.doi.org/10.1093/ageing/3.3.133.

HERCULANO-HOUZEL, S. Encephalization, neuronal excess, and neuronal index in rodents. The Anatomical Record, 2007, vol. 290, n. 10, p. 1280-1287. PMid:17847061. http://dx.doi.org/10.1002/ ar.20598.

KALLA, R., LIU, Z., XU, S., KOPPIUS, A., IMAI, Y., KLOSS, CU., KOHSAKA, S., GSCHWENDTNER, A., MÖLLER, JC., WERNER, A. and RAIVICH, G. Microglia and the early phase of immune surveillance in the axotomized facial motor nucleus: Impaired microglial activation and lymphocyte recruitment but no effect on neuronal survival or axonal regeneration in macrophage-colony stimulating factor-deficient mice. The Journal of Comparative Neurology, 2001, vol. 436, n. 2, p. 182-201. PMid:11438923. http://dx.doi.org/10.1002/cne.1060.

KANDEL, E., BARRES, BA and HUDSPETH, AJ. Nerve cells, neural circuitry, and behavior. HUDSPETH, AJ., JESSELL, TM., KANDEL, ER. and SCHWARTZ, JH. Principles of neural science. New York: Mc Graw Hill, 2013. p. 21-38.

KIERNAN, JA. Barr, el sistema nervioso humano: un punto de vista anatómico. Mexico: McGraw-Hill Interamericana, 2000.

KIERNAN, JA., SIMÓN, ON., PAZOS, TP., ANGLADA, MV., ROBBINS, J. El sistema nervioso humano: una perspectiva anatómica. Alphen aan den Rijn: Wolters Kluwer, 2009.

$\mathrm{KOCH}, \mathrm{C}$. Computation and the single neuron. Nature, 1997, vol. 385 , n. 6613, p. 207-210. PMid:9000068. http://dx.doi. org/10.1038/385207a0.

KONIGSMARK, BW. Methods for the counting of neurons. EBBESSON, SO. and NAUTA, WJ. Contemporary research methods in neuroanatomy. Amsterdam: Springer, 1970. p. 315-340.

KORSCHING, S. and THOENEN, H. Developmental changes of nerve growth factor levels in sympathetic ganglia and their target organs. Developmental Biology, 1998, vol. 126, n. 1, p. 40-46. PMid:3342935. http://dx.doi.org/10.1016/0012-1606(88)90236-9.

KREUTZBERG, GW. Microglia: a sensor for pathological events in the CNS. Trends in Neurosciences, 1996, vol. 19, n. 8, p. 312-318. PMid:8843599. http://dx.doi.org/10.1016/0166-2236(96)10049-7.

LUDERS, E., NARR, KL., THOMPSON, PM., REX, DE., WOODS, RP., DELUCA, H., JANCKE, L. and TOGA, AW. Gender effects on cortical thickness and the influence of scaling. Human Brain Mapping, 2006, vol. 27, n. 4, p. 314-324. PMid:16124013. http://dx.doi. org/10.1002/hbm.20187.

LURIJA, AR. Las funciones corticales superiores del hombre. La Habana: Ed. Orbe, 1977.

MOUNTCASTLE, VB. The columnar organization of the neocortex. Brain, 1997, vol. 120, n. 4, p. 701-722. PMid:9153131. http:// dx.doi.org/10.1093/brain/120.4.701.

NOLTE, J. El cerebro humano. Madrid: Mosby/Doyma, 1994.

NOWAKOWSKI, RS. Basic concepts of CNS development. Child Development, 1987, vol. 58, n. 3, p. 568-595. PMid:3038481. http:// dx.doi.org/10.2307/1130199.

PAKKENBERG, B. and GUNDERSEN, HJ. Neocortical neuron number in humans: effect of sex and age. The Journal of Comparative Neurology, 1997, vol. 384, n. 2, p. 312-320. PMid:9215725. http:// dx.doi.org/10.1002/(SICI)1096-9861(19970728)384:2<312::AIDCNE10>3.0.CO;2-K.

PAVON, N., VIDAL, L., BLANCO, L., ALVAREZ-FONSECA, P., TORRES-MONTOYA, A., LORIGADOS, L., ALVAREZ-GONZÁLEZ, L. and MACÍAS, R. Factores que desencadenan la muerte neuronal 
en enfermedades neurodegenerativas. Revista de Neurologia, 1998, vol. 26, n. 152, p. 554-560. PMid:9796004.

POPPER, K. and ECCLES, J. C. El Yo y su Cerebro. Barcelona: Editorial Labor, 1982.

RAO, MS. Multipotent and restricted precursors in the central nervous system. The Anatomical Record, 1999, vol. 257, n. 4, p. 137-148. PMid:10467245. http://dx.doi.org/10.1002/(SICI)10970185(19990815)257:4<137::AID-AR7>3.0.CO;2-Q.

ROSENZWEIG, MR., LEIMAN, AL., PAMIES, MP. and ALIAGA, ME. Psicología fisiológica. México: McGraw-Hill Madrid, 1992.

RUBIA, F. Áreas asociativas de la corteza cerebral.DELGADO, JM. Manual de Neurociencia. Madrid: Sintesis, 1998. p. 875-890.

SKOGLUND, T., PASCHER, R. and BERTHOLD, C-H. Aspects of the quantitative analysis of neurons in the cerebral cortex. Journal of Neuroscience Methods, 1996, vol. 70, n. 2, p. 201-210. PMid:9007760. http://dx.doi.org/10.1016/S0165-0270(96)00119-7.
STREIT, WJ. Microglial response to brain injury: a brief synopsis. Toxicologic Pathology, 2000, vol. 28, n. 1, p. 28-30. PMid:10668987. http://dx.doi.org/10.1177/019262330002800104.

THAGARD, P. La mente: introducción a las ciencias cognitivas. Buenos Aires: Katz Editores, 2008.

TORRES, H. Claustro o antemuro: otra pequeña, gran estructura cerebral. Acta Neurológica Colombiana, 1999, 15(4), 150-161.

VILHARDT, F. Microglia: phagocyte and glia cell. The International Journal of Biochemistry \& Cell Biology, 2005, vol. 37, n. 1, p. 17-21. PMid:15381143. http://dx.doi.org/10.1016/j.biocel.2004.06.010.

Received July 6, 2016 Accepted February 26, 2017 